\title{
Strategic Impacts and Ramifications of U.S-Iran Rapprochement: The End of a Beginning
}

\author{
Bakare Najimdeen (PhD) \\ Bakare Najimdeen is an assistant professor at the department of International Relations, Preston University Islamabad \\ olaaayo@gmail.com or Bakare.najimdeen@preston.edu.pk
}

\author{
Abdul Salami Ibrahim \\ Abdul Salami Ibrahim is associated with the National Defense University Islamabad \\ abdulsalamiibrahim@yahoo.com
}

\section{Doi:10.5901/ajis.2016.v5n1p153}

\begin{abstract}
American post war intervention and engagement in the larger Middle East (Middle East and Persia Gulf) is no coincidence but a calculated strategy for long term national interest. A protracted and active presence of Washington is arguably the continuity of Western imperialism in the region and thus bound to be resisted. Washington-Tehran relations predated the Islamic revolutionary that accorded a new regional and global bearing to Iran. The revolution by all accounts was one of the representations of Iranian resistance to Western imperialism. For more than three decades, U.S-Iran animosity has benefited and has been exploited by competing power centres, though of recent, the two are mending ways through diplomatic efforts that could ultimately be a defining moment for the region. The paper looks at the strategic impacts and ramifications of the new dawn in U.S-Iran relations and regional antagonism it has awoken. The paper argues that the rapprochement resonates with U.S long term interest in the region, thus short term illusions should not dissuade Washington from augmenting and consolidating the new level of relations. From a strategic standpoint, the paper avers that any sort of success story emanating from the rapprochement should be best attributed to the hard, committed and multilateral European diplomacy. The paper also discusses the corollary of the rapprochement beyond the Middle East and the nuance it provides in understanding Middle East geopolitics.
\end{abstract}

Keywords: Rapprochement, diplomacy, national interest, U.S-Iran, multilateralism

\section{Introduction}

The history of international affairs amongst empires and states is rooted in periodic competition, clash of interests and cooperation, often leading to either serious confrontational and healthy geo-politics or geo-strategic developments. Both the traditional realism (power-politics) and liberalism (alternative to power) schools have offered compelling arguments on such developments. Iran before 1979 can be characterised as a capitalist trending country, having a western-capitalist oriented king and direction. Iran during the Shah had a profound and healthy cooperation with the west and particularly with the U.S. The operational height of CIA in the reign of the Shah was itself a testimony. Although prior to the fall of the Shah, Iranians have harbored grudges against Washington, for CIA's direct involvement in August 19, 1953 coup d'etat in Iran, the latter did not merely haunt the memory of many conservative Iranians, but became a symbol of western (American) imperialism. For many Iranians (liberal and conservatives alike), the CIA coup undermined the logic of American/western democracy. The involvement of American was clearly perceived as yet a continuity of perennial western conspiracy against the region, through systematic assassination of democratically elected Prime Minister, Mohammad Mosaddeq and his cabinets (Gasiorowski, 1987, pp.261-286).

The history of Iran under the Shah will remain an incomplete chronicle without commentary about the strong attachment, relations and dependence of Iran on the United States (Saikal, 2009). The fall of the authoritarian Shah regime and the ascendance of the religio-political elites on Iran political landscape strained Iran-U.S relations, particularly the attack on U.S embassy (Jenkins, 1981). Since the embassy saga, Iran-U.S relations remain protractedly strained and stalemated by Tehran's nuclear programme.

Iran nuclear entanglement has generated debates and views from different parts of world, especially amongst western political observers swinging between correctness and illegality of Iranian's nuclear programme. Meanwhile, in a bid to resolve the deadlock, Iran has been into shuttle, back door, off and on diplomatic efforts. For many, the impasse 
over Iran's nuclear programme has shown the vulnerability of diplomacy, thus employing the hard and military approach will be the best way to dissuade Iran from her nuclear ambition. Certain section of Washington and Tel Aviv have long been tolling this line of argument (Tira, 2010, pp.45-60). Unlike the confrontational and agitation of Washington, Europeans have taken the mild approach. Enormous sanctions from the west have been part of the measures to deter and punish Iran for her political decision to continue rather than discontinue her nuclear programme. The U.S Congress led the wagon of stringent sanctions against Tehran (Huffingtonpost, 2013) though with certain degree of Europeans support (Patterson, 2013, p.136). The western-led sanctions on Iran were tailored to impair Iranian economy and ultimately sabotage her nuclear programme. International relations scholars have long debated the end result and main victims of sanction, the legality and effectiveness of sanction as tool of engagement in international politics (Esfandiary, 2013, p.6). By raining sanctions on Iran, it is hard to pin down whether the sanctions actually weaken state's capacity or threatened the Iranian society. According to Gallup polls, most Iranians blame the West, instead of their government for the itching economic consequences of the sanctions (Younis, 2013).

\section{Theoretical Discourse}

Rapprochement between states depends on multiple explanations. Recent Sino-Russia rapprochement has generated sizeable intellectual debates on the extent to which such cooperation can affect Western and particularly American interest. But one fact is sure; Sino-Russia rapprochement can be conceptualized as the agitation for an alternative world order (Marlin-Bennett, 2012). Beijing and Moscow are championing an alternative system to either offset or supplant the existing Western-centric world system. Kuchins (2009) finely expresses the intention of Beijing and Moscow geared at "a fundamental reevaluation of international political and financial institutions, reorienting them away from a Western-centric model toward a model that better reflects the true balance of power, both political and economic" (Kuchins, 2009, p.116).

International system has never been a permanent structure or phenomenon, its stability is dependent on the solidity of mutually accepted cosmo-social capital. In the post-World War II era, Sino-Russia alignment was premised on shared ideology that posed serious challenge to Western/American interest globally, especially in Europe and the Far East Asia respectively. The alignment though fractured along the way due to the strategic and ideological polemics between Beijing and Moscow (Ramachandran, 1996, pp.73-74). The ruptured Sino-Russia relations created the vacuum, wherein Sino-U.S rapprochement was seeded and nurtured. Hence, the Sino-U.S rapprochement of the 1970s surfaced following more than two decades of enmity, the rapprochement surfaced at a time, when Sino-Russia relations was seriously threatened by ideological and personality clash. Amidst international relations experts, the orthodoxy wisdom for Sino-U.S rapprochement was a result of geopolitical dilemma posed by Soviet Union against China's sovereignty and security interest. Jian's (2003), argument doesnot necessarily challenge the orthodoxy narrative, rather argues that domestic compulsion and the "fading status of Mao's continuous revolution," the inability of China to simultaneously pick two fights and maintained enmity on two sides, and the long term benefits of cooperation pushed Mao towards rapprochement (Jian, 2003, pp.26-27). In Kissinger words, Sino-U.S rapprochement "changed the world" (Cohen, 2007), shifted the global system from bipolar to tripolar and more importantly underpinned the pertinence of "national interest" and revitalization of realist logic of balance of power (Goh, 2005, pp.2-14).

Iran and Saudi are historic players within the larger geo-political landscape of the Middle East. Their contest sprawl beyond religio-political and regional issues, hegemonic tussle between the two transcends the Middle East and has gained global breadth. Irrespective of their self perceived misgivings, Al-Toraifi (2102) suggests the Saudi-Iranian rapprochement (1997-2009) was largely a result of state identity and the personality of the leaders, which explain the rise, fall, amity and enmity between the two states (Al-Toraifi, 2012). In addition to how leader's personality can change geo-political equation, Roselman added statesmanship to the debate of how Sino-U.S became a success, upon the statesmanship of Henry Kissinger (Roselman, 1990, pp.51-72).

The Cross-Strait rapprochement between China and Taiwan share similar state identity and personality of leader paradigm. Upon assuming office in 2008, Taiwan President, Ma Ying-jeou gave a new bearing to China-Taiwan relations (Denmark and Fontaine, 2009). The dramatic change delineates the new direction of foreign policy of President Ma, whose watershed and remarkable foreign policy made a departure from decades of gridlock foreign policy, brought about five substantial changes in China-Taiwan relations (Yun-han, 2009, pp. 6-86) and subsequently laid the foundation for greater opportunity for Taiwanese economy in the context of European investment, as Taiwan mends relations with China, European investors were more relaxed and stimulated towards Taipei (Erixon et al., 2012).

From a constructivist paradigm, rapprochement between states is conditioned by identity politics and cognitive integration. Franco-German rapprochement leading to the creation of EEC during the Cold War owes much to the 
calculative efforts of the European leaders, particularly Germany and France that rallied up other European leaders on the course of a common European identity (Hurrell, 1995, pp.37-75).

Security dilemma does not sufficiently captures rapprochement amongst states. Rapprochement can be triggered by structural change in the world system and order, and that was true for the Indo-US rapprochement. The end of the Cold War presented Indian policy makers limited options, forced by the systemic change to see Washington as friend, disengagement from non-alignment rhetoric, and best of all, taking advantage of whatever the sole superpower can offer. Such doing is no less a reminiscence of how China turned around her economy by accepting the Western-centric economic order, with special attention at absorbing western technology and liberal market system.

Theoretically, the unfolding US-Iran rapprochement best fit the personality/leadership trait and the urge of forging a new foreign policy paradigm. Unlike his predecessor, President Hassan Rouhani started de-freezing the long frozen relations between Washington and Tehran, similar to Taiwanese President Ma Ying-jeou's rapprochement with China. However, success of the on-going US-Iran rapprochement cannot be solely ascribed to personality trait of the leaders. Despite all domestic hurdles, the normalisation process is galvanised by the growing urban liberal population, the yearning for change, and a shift from the long cherished anti-imperialism and anti-Americanism rhetoric that has long characterised Iran.

\section{Re-emergence of the Republican Congress}

One of the strategic challenges and concerns over President Obama's negotiation tactics has arguably emerged within the Republican gripped Congress. Opinion about Iran in Washington is though not entirely favourable, particularly amongst those, who hold negative view about the entire Iranian's nuclear programme and sincerity of Iran (PEW, 2013), though sizeable American Jews approved of the nuclear agreement (Beinart, 2014).

Politically, anti-Iranian interest in Washington must seek to broaden their analysis of U.S-Iran relations beyond political agenda. They need to see the recent Obama administration's approach towards Iran with utmost fecundity. Geostrategically, U.S-Iran rapprochement will be in U.S long term interest, thus short term illusions should not dissuade Washington from augmenting and consolidating the effort of the White House. Although there is a sideline proposition that whatever the relaxed relations between U.S and Iran under Obama administration, a republican White House might undo the whole hard knotted negotiation process.

The Obama diplomatic effort is expected to create a compromising climate, wherein the Iranian nuclear programme is rollback, but not to place Iran at the nuclear threshold. Architects of the sanctions on Iran, have promised to enact yet another stringent sanction "if a potential deal does not achieve these goals," that is, a non-nuclear threshold Iran (Sanger et al., 2014). Even as the deal gets to a remarkable juncture, proponents of sanction have not concealed their desires to intensify pressure on Iran, though that has been equally exacerbated by the Iranian missile test (Gladstone, 2015). Meanwhile, President Hassan Rouhani and his Iranian negotiation team portray themselves as a team, ready to give sizeable concession, but not without a political return; sellable to the Iranian liberal and the hardliners respectively. Besides, Rouhani cautioned Washington against jeopardizing the negotiation process through further sanctions (BBC, 2014) though a report has it that the U.S economy is not exonerated from the cost of sanction on Iran (Slavin, 2014).

Rather than being disillusioned by anti-Iranian rhetoric in the region, policymakers in Washington should prioritise U.S national interest; seek the market opportunity, Iran can offer to U.S investors and most importantly the extent to which U.S strategic interest tallies with that of Tehran. It is instructive to draw analogy from Indo-U.S partnership and U.SIran cooperation.

During the Cold War, India championed the cause of the non-alignment movement, failed to queue behind Washington's worldview and viewed Washington Hobbesian adventurism as neo-imperialism. Till the end of the Cold War, Washington did not see New Delhi as potential trustworthy ally (Palmer, 1984, pp. 33-34; Kux, 2001, p.5), but that calculus is now a tale of the past given the profound Indo-US strategic partnership (Burns, 2007). If India can become a strategic ally of Washington within and outside South Asia, following an enduring non-alignment and anti-imperialist rhetoric; same can be true for Tehran.

It is high time; the doves in Washington make their voices more vocal on why the U.S must seek more engaging, progressive and post-Cold War narrative of global affairs. Branding Iran as a non-negotiable country will be tantamount to rehearsing American foreign policy before the diplomatic foresightedness of Kissinger that brought China closer to Washington. Drawing China out of its isolationist shell eventually suits the long term interest of the U.S. The Chinese economy upon 'Opening Up' got integrated into the liberal economic world order (Peng, 2007, pp.30-31), and without 
mincing word; Chinese economy is now a reckonable force amongst global economies and an influential trading partner of the U.S (OECD, 2000; Schwartz, 2012; Glickman, 2012). This can also be true for Iran upon a shift from hawkish approach towards the Persian nation. Washington hawks and corporate antagonists of U.S-Iran rapprochement reserve their right of opinion, but continuous animosity towards Iran carries more detriment than benefits. Washington and Tehran have parallel areas of strategic interest that no regional players can shoulder (Friedman, 2013a; Friedman, 2013b). The preservation of Iraq's fragile and nascent democracy is more than important for the United States than any country. Iran is capable of either solidifying or heightening that fragility. Abandoning Iraq would be tantamount to the abandonment of Afghanistan, following Soviet withdrawal; to becoming breeding ground for entities against U.S interest and even attacking the U.S homeland. Iran is an undisputed hegemonic player in the region to prevent Iraq and Syria from becoming yet another Afghanistan and haven for terrorists that can threaten U.S interest and homeland security.

The ramifications of a sustained U.S-Iran rapprochement transcend the two nations. Iran has always share the blame for fomenting and abetting Palestinians' aggression against Israel, which by extension is a jeopardy to U.S interest. Finding peace with Iran will not only reduce the tendency of Iran's facilitation of Hamas militancy against Israel, but will have far-reaching effect on the perennial Israeli-Palestinian conflict on one hand and Israel-Hezbollah on the other.

Since 1948, the United States has expended enormous U.S dollars and resources on the conflicts in the Middle East, particularly the Israeli-Palestinian conflict. Washington has earmarked billions of dollars to protect and secure Israel's existence, according to a Congressional Research Service report "to date, the United States has provided Israel $\$ 121$ billion....in bilateral assistance" (Sharp, 2014). The report asserts that "almost all U.S. bilateral aid to Israel is in the form of military assistance" (Sharp, 2014). The conflict has equally shattered U.S image as an unbiased mediator (Quandt, 2005; Marriot, 2014) giving the persistent U.S policy of rejection, the forty-two UNSC vetoes supporting Israel (Jewish Virtual Library, nd; Pilkington, 2011), and the blatant prejudice of the U.S media coverage of the conflict (McGreal, 2014). Besides, the Vanguard of U.S-Iran rapprochement should stress the extent to which the IsraeliPalestinian conflict has increasingly belittles and demystifies the omnipotence of Washington, capable enough and fairly alone to influence the resolution of Middle East conflict, particularly the Israeli-Palestinian conflict. The Israeli-Palestinian conflict is a core and contentious crisis for the Muslim world and especially for the Middle East. The uncertainty associated with the conflict partly explains the anti-Americanism in the region. U.S-Iran rapprochement has no direct relation to the Israeli-Palestinian conflict, but can tacitly proffer certain degree of antidote to anti-Americanism emerging from the unresolved conflicts in the region. U.S-Iran rapprochement can change Iran-Israel's geostrategic misperception and antipathy and can usher in a new geostrategic calculus.

\section{European Values}

At the end of every conflict is a victor and the vanquished; European value of multilateralism and exhaustive diplomatic venture should be credited for the fairly successful and sustained U.S-Iran rapprochement (Kutchesfahan, 2006; Martin, 2015). In the parlance of international relations, the new dawn and path towards negotiation on Iranian nuclear debate is generally tagged a win-win situation. Since Washington and Tehran were the central players, the outcome of the negotiation was favourable for both. But a careful dissection of the whole diplomatic adventure does not just demonstrate, but underpinned the pertinence of the indelible and uncontestable effort of the Europeans. Foremost of all, that effort rescued the world and the Middle East region particularly from yet another unwarranted belligerent adventure against Iran. Secondly, European multilateralism halted the protracted stalemate between the U.S and Iran, and by extension saved Washington from damaging her recovering economy. The (implicit and explicit) effort of the European reemphasized the essence and efficacy of diplomacy in maintaining the liberal world order as opposed to realistbellicose-power-politics. Subsequently, European diplomacy underpins and enlivens our understanding on extent to which multiple players, multidimensional approach, and the role of third party can change the bearing of an awkward event having global ramifications.

Lastly, at the end, European elites did not simply reopen economic relations with Iran, but regaining their lost niche within Iranian market. Same economic benefits should be true for American investors longing to trade with Iran, but have long been restrained by the superimposed sanctions.

Unlike the American's confrontational approach and indirect negotiation tactics, Europeans have taken the direct and cautious approach of engaging Iran over her controversial nuclear programme. Washington though was not alone in sanctioning Iran, the EU has considerable share of the international effort to dissuade Iran from acquiring nuclear capability and more importantly bring Tehran to the negotiation table. Since the onset of the nuclear stalemate and the sanctions that followed, rather than forced Iran on begging kneel, Esfandiary (2013) notes that "unilateral sanctions from 
the United States and the EU have resulted in Iran 'turning east' and boosting trade with countries in Asia" (p.6). A sustained U.S-Iran rapprochement will underpin the EU initiative of 'maximizing tactical advantages through direct negotiations with Iran' and the need for inclusive stead of exclusive and confrontational approach (Meier, 2013). Washington's realization of the need to directly engage Iran, tacitly shows the success of protracted European effort towards global and regional peace. A sustained U.S-Iran rapprochement will further consolidate the institutional efforts of the EU and facilitate individual European nations to open-up towards Iran. Obviously, a sustained U.S-Iran rapprochement will open up business and investment opportunities. It will be a comeback mission for institutions and companies that have long trade and business relations with Iran, but having fallen back due to Washington and EU sanctions. The sustained U.S-Iran rapprochement can equally reinvigorate diplomatic relations between Tehran and European countries. European value of multilateralism and dual track diplomacy deserves Washington's compensation through harmonisation of relations with Tehran. Peace in the Middle East and harmony with Iran benefits the long term interest of both the U.S and Europeans, hence European diplomatic efforts to resolving the deadlock should at least be compensated by the U.S, in such a way that anti-Iranian caucus won't truncate or jeopardize the whole European efforts. Compensating the Europeans would equally lead to the resumption of Europe-Iran economic dealings, energy dealing and by extension alleviation from Russia energy clout.

\section{Iran's Political Dynamics}

The new political wave in Iran brought forth a moderate face of Iran in the shape of President Hassan Rouhani and his foreign minister, Mohammad Javad Zarif respectively. Despite domestic challenges amongst Iran religious hardliners and the Revolutionary Guards Corps, the powerful security and military organization, responsible for the protection and survival of the regime (Nader, 2010), the president and his foreign ministers have been reaching out to the west. Such propensity has received warm gestures in Europe, though of lesser degree in Washington, but evidently not amongst Washington hardliners, drumming the beats of war. Rouhani's mild approach makes him distinctive from his predecessor, though Iran is said to be trending this mild route due to the effect of Washington's sanctions on Iranian economy (Slavin, 2014), an assertion that has been refuted (Parsi,2014). Iran's political system and structure has long been the source of debates. For many, the Iranian political system is complicated and does not fit into modern framework of democracy, even though Iranians have long displayed democratic culture in the selection of public officers. Iran operates a presidential-cum-parliamentary system, coupled with established religious elite, whom by status is overarching in decision making. Of recent the Iranian supreme leader, Ayatollah Ali Khamenei is reported shuttling hospital, an indication of weak health and prospect of being changed if his health further deteriorates. The fact that the supreme leader oversees and holds the final discretion on the bearing of Iran was argued to be dangerous for the future of the negotiation vague, but event prior and after the nuclear deal suggest otherwise (Arms Control Association, 2015). In the wordings of the Arms Control Association "the Agreement Creates a Strong, Effective Barrier Against a Nuclear-Armed Iran.....the agreement.....achieved a verifiable, comprehensive agreement to limit Iran's sensitive nuclear activities is a historic breakthrough for nuclear nonproliferation and international security." (Arms Control Association, 2015). The breakthrough undoubtedly shows that irrespective of the conservatism of the supreme leader, he remains a leader who is not necessarily and extremely oppose to rational decision (Ganji, 2013). The question arises, how much concession the current supreme and in-coming supreme leader, who is more likely to emerge amongst the hardliner religious elite would accord the U.S-Iran rapprochement. The supreme leader is expected to preserve the bequeathed legacy of the revolution. One thing is unique in the whole saga; the supreme leader has been comfortably able to manage the sentiments of all Iranian stakeholders. The supreme leader has reckoned with the narrative of the president and simultaneously concurred with the Revolutionary Guards Corps on extent to which Iran can compromise her national interest.

\subsection{Does Iran Really wants the Bomb}

Besides the prestige of holding the status of a nuclear power state, the goal of the Iranian leadership during the nuclear debacle and within the larger picture of conflict with the West was geared at achieving a stable and viable economy, resilience enough to weather regional and global challenges. Iran was under a collective U.S-led sanction, which arguably wounded but never crippled Iranian economy (Ghezelbash \& Parsi, 2015). Tehran needs a blossom economy for many reasons. Internally, Iranian leadership has to fulfill her domestic needs. Two, at the regional level, a viable economy would accord Iran financial integrity to influencing affairs in the region through soft measures without 
necessarily resorting and employing hard ways. More importantly, a buoyant economy will be an undisputable diplomatic tool for Iran to compete with her Arab rich neighbours. At the global front, Iran needs burgeoning economy, healthy enough to encourage and stimulate foreign investments on one hand and on the other, an opportunity for foreign companies to harness the potential of domestic capabilities of Iran's economy. The nuclear deal is thus not necessarily to achieving nuclear potential, but to untie unnecessary hurdles knitted to the Iranian economy. Invariably, neither the Iranian leadership nor the Europeans, who have been a party to the sanction, are naïve of the potential of Iranian economy. The swift European response and tours to Iran following the nuclear deal are incontestable testimony. Europe must reclaim her niche in the Iranian market, amidst growing competition. While European investors were on relative short economic vacation, players like (China, Russia, India and South Korea) took advantage of the vacuum (Ghezelbash \& Parsi, 2015). It would be a misleading argument to suggest that foreign players would be the sole beneficiary of the new dawn in Iran's global political-economy; rather Tehran is equally gearing up to welcoming more of foreign "technology transfers, technical know-how, long-term investments and the basing of manufacturing in Iran" (Ghezelbash \& Parsi, 2015). the final success of this new dawn though will largely depend on Europeans tactical diplomacy geared at salvaging the whole deal from being sabotaged by domestic and foreign (Iranian American/Israeli) saboteurs.

\section{Arms Race and Deepen Sectarian Divide}

Among Iran rivals, western opposition and sanction on Iran is directly relational to their national interest and foreign policy goal. Hence, the continuity of Iran-U.S discord satisfies long term interest than any form of rapprochement. At the peak of the Syria crisis, competing forces turned Syria into a proxy ground. The end result was the winning team of Russia, Iran and Syria, while the team of Saudi Arabia, Turkey and the Emiratis have failed to accomplish their objectives. The Syrian outcome certainly strained Saudi-U.S relations; undoubtedly the current situation will most likely be exacerbated by any sort of harmonious relations between Iran and Washington. The Saudis have made their point loud and clear that U.SIran rapprochement could eventually give the Iranian certain degree of nuclear leverage and ultimately reason for an irrational arms race in the region. The Saudis' narrative is rooted in sectarian and geopolitics rhetoric. Riyadh has vowed to proceed and maintain whatever level of nuclear concession Iran is given (Sanger et al., 2014). Geo-strategically, Tehran and Riyadh have picked fight at different proxy arenas (Bahrain, Iraq and Syria, Lebanon). Hegemonic tussle between the two transcends geo-politics, but rather transnational and religiously tainted. Sectarian polarization will further accentuate as one party would construe such rapprochement as support. Besides, the Saudis can exploit the new scenario to galvanize more Sunni friends to their cause. By flagging and chanting the Sunni mantra will give credence to such cause. Ordinarily, national interest might be the centrality of Saudi motive, but religious and sectarian gain will be no exemption. U.S-Iran rapprochement has complicated the Cold War and rivalry relations between Iran and Saudi Arabia. The whole tragic episode during the last pilgrimage (Hajj) to Mecca and recent execution of Sheikh Nimr resonates with the enduring tension between the two (Maher, 2016).

\section{Russia and Saudi Oil}

U.S and European sanctions have substantially reduced the status of Iran as the third oil producing country. Since its economy largely depends on the oil sector, the blow of the sanction on the sector cannot be understated. While the Iranian economy suffered due to the just lifted sanctions, other oil and gas producing countries have satisfactorily exploited the vacuum of Iran. Thus, any form of rapprochement will not just rebound the Iranian economy, ease economic hardship at the national level, but will be a springboard for Iran comeback in global oil production. The global oil price is witnessing a price drop, which obviously affects the oil producers, by having more of Iranian oil in the market; this could further send the oil price curve downward. In the best interest of countries like Russia, Saudi, Nigeria and other OPEC countries, the status-quo between Tehran and Washington should remain unchanged.

\section{Oil Energy and Game}

Prior to the Ukrainian political fiasco, Europeans would accuse Moscow of taking advantage of her energy resources for political maneuver (Barysch, 2008, p.2), even if such allegation is true, from a realist standpoint that is in the best interest of Russia and rational choice theory suggests every state will behave in similar way. The relationship between Russia and Ukraine goes beyond historical and cultural bond; Ukraine has always been the energy transit between Russia and Europe and at the same time a geo-strategic shield for Russia against European (NATO) incursion into mainland Russia. 
Prior to the U.S and European sanctions on Iran, Europe substantially relies on Iran for energy supply (Verleger Jr, 2012). The sanction on Iran gave Russia more leeway to discretionally punish her European neighbours with her energy leverage. European sanctions on Iran is no doubt embedded with pros and cons, in the interest of the European; having Iran back as energy supplier will suits the continent interest and will not just offset Moscow energy hegemony, but will equally drawdown much reliance on Moscow. Although, the EU in general and Germany in particular often takes cautious and diplomatic approach towards Russia, the latter needs Germany's technology, while Berlin needs Russia energy. However, the tone of Germany is turning tough on Moscow as was evident during Chancellor Merkel's speech in Australia (Hill, 2014).

\section{Pakistan-Iran Rapport}

Pakistan since independence has been in strategic alliance and relations with the United States, even when her neighbour India was championing the cause of the non-alignment movement (NAM), Pakistan remained with Washington. Seemingly, the relations between Islamabad and Washington have never been an all-weather friendship, it has seen lot of oscillation (Kux, 2001), even when Islamabad's interest is at stake; Islamabad would relatively please Washington, as in the case of war on terror (Pakistan Today, 2013). Such assertion might appear unpleasant, but the case of the pipeline involving Iran and Pakistan is another recent example (Maitra, 2005). Despite all media stunt and diplomatic effort to kickstart the project, the uneasiness between Washington and Iran have made the project a sleeping ambition (Fazl-e-Haider, 2014). Pakistan is truly under the attack of energy crisis, electricity supply is increasingly becoming an affluent amenity, industries are at stake and many are either outsourcing their business elsewhere to the neighbouring countries or becoming industries of the past. Being a neighbour, Iran has offered Pakistan good gesture in terms of energy (Dawn, 2014), but sanction and international tag on Iran puts Pakistan at a tight corner. Evidently, U.S-Iran rapprochement will have good strategic implication for Pakistan as the sleeping projects and redundant cooperation would be reignited, hence spurring economic growth for both countries. Besides, being neighbours and having closer understanding of certain issues in the region, Washington can rely on Iran-Pakistan relations as guarantee for U.S interest in the region, upon Washington exit from the region. But that is a possibility giving the rapprochement with Iran and balance relation with Pakistan. U.S-Iran rapprochement will bring enormous relief to the region. Amongst Pakistani, Indian, Afghan and Kashmiri Muslims, there is both implicit and explicit grievance against the U.S that Iran another Muslim nation could be invaded. Anti-Americanism is not just about the nature of U.S attitudes and policies, but the manifestation of such attitudes and policies is perceived by Muslims as endangering to their religion, territories and integrity as citizens of the world.

\section{Iran-US Cooperation in Iraq}

Prior to the first Gulf war, the preceding Iran-Iraq war had already caused damage to the region. Although there are numerous arguments on the root causes of the war, but one established and indelible fact remains, Iraq was used as proxy against the clergy government in Iran. The latter suffered immensely during the war, was tortured directly through U.S sanction, and above all, harboured grudges against Washington for the latter support, that allowed Iraq to unfairly use very lethal weapons on Iran (Harris \& Aid, 2013). The bond between Iraq and U.S could not stand the test of time given the policies of Saddam in the region. Such policy was culminated by Saddam's occupation of Kuwait, which eventually unleashed U.S wrath and thus the 1990s Iraq war. By 2003, U.S dealt the final blow on Saddam regime, which in fact was not the end of crisis in Iraq, rather paved way for the beginning of a great competition, though asymmetric between the Iraqi Sunni and Shia community on one hand, and Iran and U.S on the other (Mausner et al, 2012). Since the fall of Saddam, and the ascendance of Shia government in Baghdad, the hand of Iran on Iraqi domestic politics has remained a recurring phenomenon (Friedman, 2011). The growing influence of Iran in Iraq and the entire region is a development Washington has no propensity to stop or contained, instead the latter has concurred with the ground reality as a matter of necessity. The rising Sunni insurgency and the ISIS militancy are bound to undermine whatever achievement the U.S could claim in Iraq. No regional power stands the position save Iran to help the Americans maintain strategic peace in Iraq and thus explains the Iran-U.S rapprochement (Friedman, 2013). Notably, the fall of Saddam, the wreck of Syria and the uncertainty in Egypt has left the region with no decisive power; even the Saudis and Turks cannot claim unquestionable hegemony. However, the direct and indirect geo-political and geo-strategic displays of Iran in recent time leaves Tehran as the "dominant power in the Persian Gulf" though "this poses a fundamental challenge both for American strategy and the extremely complex region" (Stratfor Analysis, 2014). Yet the volatility in Iraq, the entire Middle 
East, and the increasing menace of ISIS leaves Washington with limited option, hence the covert and overt cooperation with Iran in overall Iraq stability (Mausner et al, 2012). To sustain Americans' achievements in Iraq, to prevent Syria from falling into the wrong hands in post-Bashar era, even though regime change in Syria is now a crossed question; and preventing the eventuality of the region turning into another sanctuary against U.S strategic interest, Washington must reconcile with Tehran through a sustainable rapprochement.

\section{Israel Factor}

Even if the Turks and Saudis along with the Emirati leaders are prepared to accept the reality of a nuclear Iran; Israel would definitely be an exemption. The state of Israel has never for once ceased to play the existential narrative against Iranian nuclear programme. Such narrative gets good reception in Washington, but relatively lower accord amongst Europeans, who do not see Iran as a direct threat, rather sees Israel cry over Iranian nuclear programme as a shield for its own programme. The conservative Israeli government has continuously portray Iran as rogue state, and asserts Iran as untrustworthy, amidst such arguments is U.S-Iran rapprochement, which implicitly shows the failure of warmongering lobbyists and the desire of Israel. Permitting the rapprochement to go forth could eventually bring Israel's existential narrative to the drain. The extent to which a successful U.S-Iran rapprochement will change U.S-Israel strategy alliance remains vague, unfolding events will tell. Although U.S-Iran rapprochement will serve long term interest of Israel, her perceived threat from Syria, Lebanese Hezbollah and HAMAS will become a tale of the past. Although, the Israelis are bound to be fearful of any form of U.S-Iran rapprochement and by extension the P5+1 nations and Iran nuclear deal. The deal though attempts to strangle the possibility of Iran becoming a nuclear state, yet the details of the deal will add-up to the existing nuclear and arms control regime. Such has no benefit for Israel because at a juncture; Tel Aviv might be drawn into same regime and control ring, even though Israel has maintained the status of undeclared nuclear capable state (Evron, 1994), a position not unknown to the region and to the informed members of the international community.

\section{Conclusion}

Without mincing words, European efforts (covert and overt) in the actualization of the rapprochement demand a great deal of acknowledgement. The new dawn between Washington and Tehran reemphasized the relevance of (Europe), the old continent in global geopolitics. For any serious and closer observation, neither Iran nor Washington should claim victory out of the whole saga; instead European multilateralism and dual track diplomacy should be accorded the winner's trophy. Europeans have displayed that regardless of their own internal crisis, they still have degree of clout to sway global affairs towards mutually acceptable terms.

Arguably, if the U.S-Iran rapprochement is sustained for a longer time than expected, it should be a great credit for Iran that has come a long way from isolation, confronted by international stigma, condemnation and sanction. U.S-Iran rapprochement can best be placed within the framework of strategic convenience, fatigued and unproductive decades of impasses. U.S has long been dragged in almost decades of fight in the Muslim world, conflict that has brought the American economy wounds than pleasure, and to certain degree raised the rhythm of anti-Americanism particularly in the Muslim world. America today is not ready and shifting from policing the world alone, or shouldering the challenges of the globe without companions, hence the pathway and the realisation of U.S-Iran rapprochement. The latter brings aboard the Iranians, accords more swaying power to Tehran and facilitates a geopolitics environment mutually managed by Washington and Tehran; even though it does not totally suits Washington. U.S-Iran rapprochement is more a convenient way to sabotage the challenges in the region. Regional rivalry would not cease, it is clearly manifesting that a geopolitical understanding between Washington and Tehran redefines regional equation, yet Iran's rivals would have to condone the ground reality, meanwhile Washington needs to measure the suitability of the new dawn in terms of her own interest than suiting others. Both Washington and Tehran cannot afford any sort of jeopardy; such risk will bear long term peril and importantly undermines the whole effort of the Europeans, who are ready to keep the tranquility of the hard-laboured understanding and equation.

Pakistan is a neighbour of Iran, it behooves the government to facilitate the process than being indifferent, cooperation between the two neighbouring countries will strengthen relations and bring forth composite effort towards shared issues. Both countries have number of areas to cooperate, in the areas of economy, fight against extremism and terrorism, promotion of interfaith and cultural alliance and more importantly good neighbourhood. 


\section{References}

Al-Toraifi, A. (2012). Understanding the role of state identity in foreign policy decision-making: the rise and demise of Saudi-Iranian rapprochement (1997-2009). PhD dissertation, The London School of Economics and Political Science.

Arms Control Association. (2015, July 14). "P5+1 Nations and Iran reach historic nuclear deal. press release. https://www.armscontrol. org/pressroom/press-release/2015-07-14/P5-Plus-1-Nations-and-Iran-Reach-Historic-Nuclear-Deal

Barysch, K. (2008). Pipelines, politics and power: the future of EU-Russia energy relations. Centre for European Reform, $271-851$. http://www.cer.org.uk/sites/default/files/publications/attachments/pdf/2011/rp_851-271.pdf

BBC. (2014, August 30). Iran President Rouhani hits out at US sanctions. http://www.bbc.com/news/world-middle-east-28997452

Beinart, P. (2014, January 21). The only 'leader' who speaks for American Jews on Iran is Barack Obama. Haaretz. http://www.haaretz. com/opinion/.premium-1.569957

Borger, J. (2014, January 15). The truth about Israel's secret nuclear arsenal. The Guardian. http://www.theguardian.com/world/2014/ jan/15/truth-israels-secret-nuclear-arsenal

Burns, N. (2007, November/December). America's Strategic Opportunity with India: the new U.S.-India partnership. Foreign Affairs, issue. https://www.foreignaffairs.com/articles/asia/2007-11-01/americas-strategic-opportunity-india

Cohen, I. W. (2007, March/April). Chinese lessons: Nixon, Mao, and the course of U.S.-Chinese relations. Foreign Affairs, issue. http://www.foreignaffairs.com/articles/62462/warren-i-cohen/chinese-lessons-nixon-mao-and-the-course-of-u-s-chinese-relations

Dawn. (2014, July 3). Iran wants to help Pakistan in energy sector. http://www.dawn.com/news/1116706

Denmark M. A. \& Richard, F. (2009, December). Taiwan's gamble: the cross-strait rapprochement and its implications for U.S. Policy, Policy Brief: Centre for a New American Security. http://www.cnas.org/files/documents/publications/Taiwan_Denmark_Dec2009_ code502_policybrief2.pdf

Esfandiary, D. (2013). Assessing the European Union's sanctions policy: Iran as a case study. EU Non-Proliferation Consortium, (34), 6-20. www.nonproliferation.eu/documents/.../dinaesfandiary52b41ff5cbaf6.pd.

Erixon, F., Michal K., \& Natalia, M. (2012). After cross-strait rapprochement: a conceptual analysis of potential gains to Europe from ChinaTaiwan economic cooperation. ECIPE Occasional Paper, (3). http://www.ecipe.org/media/publication_pdfs/OCC32012.pdf

Evron, Y. (1994). Israel's Nuclear Dilemma. New York: Routledge.

Friedman, G. (2013a, November). The U.S.-Iran talks: ideology and necessity. Stratfor. http://www.stratfor.com/weekly/us-iran-talks-ideology-andnecessity?utm_source=freelist-f\&utm_medium=email\&utm_campaign=20131112\&utm_term=Gweekly\&utm_ content=readmore\&elq=6930d88ce9a54bb28e407d74165cc04f (Accessed December $\overline{9}, 2014$ ).

Friedman, G. (2013b, October). U.S. and Iranian realities. Stratfor. http://www.stratfor.com/weekly/us-and-iranian-realities\#axzz3JWIds0 g8

Friedman, G. (2011, April). Iraq, Iran and the next move. Stratfor. http://www.stratfor.com/weekly/20110425-iraq-iran-and-next-move\# axzz3JWlds0g8

Ganji, A. (2013, September/October). Who is Ali Khamenei?: the worldview of Iran's supreme leader, Foreign Policy. http://www.foreignaffairs.com/articles/139643/akbar-ganji/who-is-ali-khamenei

Gasiorowski, M. J. (1987). The 1953 Coup D'etat in Iran. International Journal of Middle East Studies, 19(3), 261-286.

Ghezelbash, \& A. Rouzbeh, P. (2015). The obstacles ahead in Europe's race to trade with post-sanctions Iran, World Politics Review. http://www.worldpoliticsreview.com/articles/16499/the-obstacles-ahead-in- europe-s-race-to-trade-with-post-sanctions-iran

Gladstone, R. (2015, December 31). Iran denounces U.S. sanctions over missiles, saying it will build more. New York Times. http://www.nytimes.com/2016/01/01/world/middleeast/iran-sanctions-missiles.html?emc=edit_th_20160101\&nl=todaysheadlines \&nlid=49519343\&_r=0

Glickman, D. (2012). China's growth and trade: consequences for the U.S economy. The Aspen Institute, 27(1).

Goh, E. (2005). Constructing the U.S. rapprochement with China, 1961-1974: from "red menace" to "tacit ally. Cambridge University Press, 2-14.

Harris, S., \& Matthew, A. M. (2013, August). CIA files prove America Helped Saddam as He Gassed Iran. Foreign Policy. http://www.foreignpolicy.com/articles/2013/08/25/secret_cia_files_prove_america_helped_saddam_as_he_gassed_iran

Hill, J. (2014, November 19). Germany's Merkel toughens tone with Russia's Putin. BBC News. http://www.bbc.com/news/world-europe30104676

Hurrell, A. (1995). Regionalism in theoretical perspective. In L. Fawcett \& A. Hurrell (Eds.), Regionalism in World Politics: Regional Organisation and International Order (pp 37-75). Oxford: Oxford University Press.

Iran sanctions bill from Sens. Bob Menendez and Mark Kirk could endanger U.S. negotiations. (2013, December 19). Huffingtonpost. http://www.huffingtonpost.com/2013/12/19/iran-sanctions-bill_n_4472439.html

Jenkins, B. M. (1981). Embassies under siege: a review of 48 embassy takeovers, 1971-1980. RAND. www.rand.org/content/dam/rand/ pubs/reports/2005/R2651.pdf

Jewish Virtual Library. (nd.). U.N Security Council: U.S vetoes of resolutions critical of Israel from 1972 to Present. www.jewishvirtual library.org/justice/UN/usvetoes.html

Jian, C. (2003). The path toward Sino-American rapprochement, 1969-1972. German Historical Institute, Bulletin Supplement (1), $26-27$.

J.P. Morgan. (2012). China's economic and political trends and their impact on the U.S. https://www.jpmorgan.com/cm/BlobServer/ China_s_Economic_and_Political_Trends.pdf?blobkey=id\&blobwhere=1320602031429\&blobheader=application/pdf\&blobheadername1= Cache-

Kuchins, A. C. (2009). Releveraging U.S. power amid Sino-Russian rapprochement. In C. McGiffert (Eds.), Chinese Soft Power and Its Implications for the United States Competition and Cooperation in the Developing World (pp 116-134). CSIS Report. http://csis.org/files/media/csis/pubs/090403_mcgiffert_chinesesoftpower_web.pdf (Accessed December 9, 2014).

Kutchesfahan, Sara. (2006, March). Iran's nuclear challenge and European diplomacy. European Policy Centre, Issue Paper (46). http://www.epc.eu/documents/uploads/89544050_IranlP.pdf

Kux, D. (2001). The United States and Pakistan, 1947-200: disenchanted allies. Karachi: Oxford University Press. 
Maher, A. (2016, January 12). Saudi-Iran Tensions sharpen Iraq's Sectarian Divide. BBC. http://www.bbc.com/news/world-middle-east-35279263 Maitra, R. (2005, August 12). Has India sacrificed at Washington's altar?. Asia Times. http://www.atimes.com/atimes/South_Asia/GH 12Df03.html Marlin-B. R. (2012). Alker and IR: Global Studies in an interconnected world. New York: Routledge.

Marriott, D. (2014, August 19). The US needs to increase its role in the Israeli-Palestinian peace process, not lessen it. Huffington Post. http://www.huffingtonpost.co.uk/daniel-marriott/the-us-needs-to-increase-role-israel-palestine_b 5689772.html

Martin, Garret. (2015, May). European diplomacy and the Iranian nuclear negotiations. The European Institute. http://www.europeaninstitute.org/index.php/ei-blog/252-european-affairs/ea-may-2015/2066-auto-generate-from-title

Mausner, A., Sam K., Anthony H. C., Peter A., \& Charles, L. (2012, March). The outcome of invasion: US and Iranian strategic competition in Iraq. CSIS Report. http://csis.org/files/publication/120308_Combined_Iraq_Chapter.pdf

McGreal, C. (2014, July 31). American media's new pro-Israel bias: the same party line at the wrong time. The Guardian. http://www.theguardian.com/commentisfree/2014/jul/31/american-media-israel-bias-netanyahu

Meier, O. (2013). European efforts to solve the conflict over Iran's Nuclear programme: how has the European Union performed?. EU NonProliferation Consortium, 27. www.sipri.org/research/.../eu-consortium/.../nonproliferation-paper-27

OECD, (2000). Main determinants and impacts of foreign direct investment on china's economy. OECD Working Papers on International Investment, 4. http://www.oecd.org/investment/investment-policy/WP-2000_4.pdf

Pakistan Today. (2013, March 7). Pakistan sacrificed greatly in war on terror: Gen Mattis. http://www.pakistantoday.com.pk/2013/03/07/ national/pakistan-sacrificed-greatly-in-war-on-terror-gen-mattis/

Palmer, N. D. (1984). The United States and India: The dimensions of influence. New York: Praeger Publisher.

Parsi, T. (2014, May). No, sanctions didn't force Iran to make a deal. Foreign Policy. http://www.foreignpolicy.com/articles/2014/05/ 14/sanctions_did_not_force_iran_to_make_a_deal_nuclear_enrichment (Accessed December 19, 2014).

Patterson, R. (2013). EU sanctions on Iran: the European political context. Middle East Policy, 20 (1), 136. http://mepc.org/journal/ middle-eastpolicy-archives/eu-sanctions-iran-european-political-context.

Peng, Y. (2007). A harmonious world and china's new diplomacy. Contemporary International Relations, 17(3), 30-31.

Pew Centre for the People and the Press. (2013). Limited support for Iran nuclear agreement. http://www.people-press.org/2013/12/09/ limitedsupport-for-iran-nuclear-agreement/

Pilkington, E. (2011, February 19). U.S vetoes UN Condemnation of Israeli Settlements. The Guardian. www.theguardian.com/world/2011/feb/usveto-israeli-settlement

Posch, Walter. (nd.). Iran and the European Union. USIP. http://iranprimer.usip.org/sites/iranprimer.usip.org/files//ran\%20and\%20the\% 20European\%20Union.pdf

Quandt, W. B. (2005). Peace process: American diplomacy and the Arab-Israeli conflict since 1967. Washington: Brookings Institution Press.

Roselman, J. D. (1990). Chinese rapprochement under Nixon: a case study in foreign policy bureaucracy and decision-making. The Fellows Review, 51-72. rockefeller.dartmouth.edu/studentopps/josh_roselman_paper.pdf

Saikal, A. (2009). The rise and fall of the shah: Iran from autocracy to religious rule. New Jersey: Princeton University Press.

Sanger, D. E., Steven, E., \& Jodi, R. (2014, November 16). Iran nuclear pact faces an array of opposing forces. New York Times. http://www.nytimes.com/2014/11/17/world/middleeast/nuclear-deal-with-iran-runs-into-obstacles-.html?emc=edit_th_20141117 \&nl= todaysheadlines\&nlid=49519343\&_r=0)

Schwartz, N. D. (2012, October 22). China's doldrums put pressure on U.S. exporters. New York Times. http://www.nytimes.com/ 2012/10/23/business/global/chinas-slowing-economy-puts-pressure-on-american-exporters.html?pagewanted=all\&_r=0

Sharp, J. M. (2014, April). U.S. foreign aid to Israel. Congressional Research Service. 7-5700, RL33222. https://fas.org/sgp/crs/mideast/ RL33222.pdf.

Slavin, B. (2014, November 11). Sanctions, politics complicate Iran nuclear deal. Aljazeera, http://america.aljazeera.com/articles/2014/ 11/11/sanctionspoliticscomplicateirannucleardeal.html

Slavin, B. (2014, July 15). Iran sanctions cost US economy billions, report says. Al-monitor. http://www.al-monitor.com/pulse/ originals/2014/07/iran-sanctions-cost-us-economy-billions-report.html

Stratfor Analysis. (2014, January). Strategic reversal: the United States, Iran, and the Middle East. http://www.stratfor.com/analysis/ strategicreversal-united-states-iran-and-middle-east\#axzz3JWlds0g8

Syed F. H. (2014, November 15). Big powers block Iran-Pakistan gas pipeline plans. The National. http://www.thenational.ae/ business/energy/big-powers-block-iran-pakistan-gas-pipeline-plans

Tira, R. (2010). A military attack on Iran? considerations for Israeli decision making. Strategic Assessment, 13(1) 45-60. http://www.inss.org.il/uploadimages/Import/\%28FILE\%291279454147.pdf

Verleger, Jr, P. K. (2012, February). Using U.S strategic reserves to moderate potential oil price increases from sanctions on Iran. IIE Policy Brief. http://www.iie.com/publications/pb/pb12-6.pdf

Younis, M. (2013, February). Iranians feel bite of sanctions, blame U.S., not own leaders: most support nuclear program despite sanctions," Gallup. http://www.gallup.com/poll/160358/iranians-feel-bite-sanctions-blame-not-own- leaders.aspx

Yun-han, C. (2009). Rapprochement in the Taiwan strait: opportunities and challenges for Taipei. East Asian Policy, 1(4), 76-86. www.eai.nus.edu.sg/Vol1No4_ChuYunhan.pdf 